\title{
One Minute After Birth
}

National Cancer Institute

\section{Source}

National Cancer Institute. One Minute After Birth. NCI Thesaurus. Code C81227.

The actual time that is one minute after the birth of a fetus. This period is most commonly referenced during the administration of the Apgar test. 